\title{
JULGAMENTO DO TCU QUE REPROVOU CONTAS DO GOVERNO ENTROU PARA A HISTÓRIA DO DIREITO FINANCEIRO
}

Coluna publicada em 20.10.2015: <http://www.conjur.com.br/2015-out-20/ contas-vista-julgamento-tcu-entrou-historia-direito-financeiro $>$

O dia 7 de outubro de 2015 entrou para a história do Direito Financeiro e não podia deixar de ser mencionado nesta coluna que se dedica ao tema há mais de três anos.

O julgamento do Tribunal de Contas da União que reprovou por unanimidade as contas de governo da administração pública federal de 2014 foi relevante sob muitos aspectos.

Em primeiro lugar, foi importante notar que esse órgão, criado em 1890 e instalado em 1893, sobre o qual já falei em coluna publicada em 14 de janeiro de 2014 (Tribunais de contas são os guardióes do dinheiro público), exerce funções da maior relevância para o Estado Democrático de Direito, especialmente no que toca às questôes de Direito Financeiro, sendo dotado de autonomia para exercer sua missão. Esse julgamento foi uma demonstração clara de que o Tribunal não é subserviente aos donos do poder e mostrou total independência ao tomar a decisão que reprovou as contas do mais alto mandatário da nação.

Também mostrou que as normas de finanças públicas, com destaque para a Lei de Responsabilidade Fiscal, além das demais que regulam a atividade financeira do Estado, existem para ser cumpridas por todos, e com rigor. Afirmou a relevância do Direito Financeiro para a administração pública, dando um exemplo aos gestores públicos de que todos estão sujeitos ao império da lei, por mais alta que seja a autoridade.

As "maquiagens contábeis", já objeto de referência nesta coluna há mais de dois anos (Carnaval financeiro: contas "maquiadas" não vão tornar nosso país mais bonito, publicada em 12 de fevereiro de 2013), as "pedaladas fiscais", de todos co- 
nhecidas, sobre as quais já nos referimos mais de uma vez (Atençãa caro leitor, pedalar faz mal à saúde!, publicada em 23 de setembro de 2014, e Cuidado, pedalar pode dar cadeia!, publicada em 5 de maio de 2015), e a irresponsabilidade fiscal, também evidente nos últimos anos (Colunas $O$ direito financeiro precisa ser levado a sério, e 2015 começou mal, publicada em 10 de fevereiro de 2015, e Irresponsabilidade fiscal ainda persiste, 15 anos após a publicação da lei, publicada em 7 de abril de 2015), perfazem um conjunto de "malfeitos" financeiros que não poderiam ter outro destino.

Julgar as contas com rigor (veja-se também a coluna Julgamento das contas do governo precisa ser feito com rigor, publicada em 30 de junho de 2015) foi a decisão que se esperava para não se deixar consolidar um comportamento reiterado de desobediência às normas vigentes em matéria de finanças públicas, o que causa prejuízo não somente à segurança jurídica, mas também à credibilidade de todo o ordenamento jurídico e dos governantes, e resulta em danos imediatos e diretos à economia do país como um todo.

Justiça deve ser feita também à destacada atuação do Ministério Público de Contas, instituição que, como já destaquei, pode ser pequena em sua dimensão, mas é grande na sua importância, e foi responsável por formalizar, fundamentar e instruir com competência a representação que resultou na investigação e decisão final opinando pela rejeição das contas, mantendo-se firme e vigilante durante todo o processo na defesa do interesse público para assegurar a aplicação da legislação vigente e higidez nas contas públicas, ameaçadas pelos desmandos que vieram a ser reconhecidos pelo Tribunal. Uma demonstração de quão relevante é ter autonomia e independência no exercício de suas funções.

Ante o caráter técnico do corpo funcional do Tribunal de Contas da União, constituído por servidores concursados de inegável competência, e a unanimidade da decisão, acolhida por todos os Conselheiros, em sua maior parte nomeada nos últimos dez anos, não há como ter dúvidas sobre existência das irregularidades apontadas, tornando insubsistentes as alegações de que tenha natureza e interesse político.

É certo que, no que tange ao julgamento das contas do governo federal, apresentadas pela Presidente, como é o caso, a decisão do TCU tem natureza opinativa, inserindo-se no rol das atividades que integram a função consultiva do Tribunal.

A decisão definitiva compete ao Congresso Nacional, a quem caberá, julgá-las, nos termos do artigo 49, IX, da Constituição, sendo possível não acolher o parecer em que se consubstancia a decisão do Tribunal de Contas. Daí porque a relevância de um trabalho que se mostrou consistente e bem elaborado, não sendo 
aceitável um julgamento em sentido diverso - o que caracterizaria, aí sim, uma decisão de natureza eminentemente política e desconectada da realidade dos fatos apurados e analisados tecnicamente.

Por oportuno, é relevante destacar que, entre as várias atividades dos Tribunais de Contas, a apreciação das contas anualmente apresentadas produz documentos de elevada qualidade no que tange à avaliação das atividades governamentais, com destaque para os aspectos administrativos e financeiros.

Boa parte dos avanços experimentados pela administração pública nos últimos anos tem origem nas constatações, recomendaçóes e sugestóes contidas nos pareceres anuais sobre as contas de governo.

Apenas para citar o exemplo deste último relatório, ${ }^{1}$ vê-se, à semelhança do que tem ocorrido nos anos anteriores, haver sido feito um valioso trabalho que abrangeu não só os aspectos financeiros das contas, mas da gestão como um todo, em uma visão macro, como se espera em se tratando da apreciação das contas de governo. Há uma detalhada análise do desempenho da economia brasileira em seus diversos aspectos (inflação, emprego, PIB, carga tributária, política macroeconômica, dívida pública etc.) e uma avaliação do sistema de planejamento governamental, do comportamento da arrecadação federal e da distribuição dos recursos no orçamento, incluindo os benefícios fiscais e creditícios, bem como da execução orçamentária. $\mathrm{Na}$ apreciação da ação setorial do governo, os vários programas que integram o PAC - Programa de Aceleração do Crescimento e o PPA 2012-2015 são avaliados quanto a seu desempenho, o que permite constatar com muito mais clareza a adequação da aplicação dos recursos públicos, identificando as falhas e permitindo o aperfeiçoamento da gestão.

Com isso, os alertas, recomendações e sugestões ganham consistência, e as considerações acerca da governança pública ${ }^{2}$ dão verdadeira aula de como aperfeiçoar a gestão, mostrando que, mais do que um documento voltado a punir os maus gestores pelas irregularidades encontradas, tem caráter predominantemente educativo e propositivo, destinado a promover melhorias na administração pública.

É fundamental que essa decisão histórica resulte na punição pelas inúmeras irregularidades constatadas pelo TCU, como os pagamentos postergados por meio do financiamento pelos bancos públicos (as já famosas "pedaladas fiscais"), omissões de passivos no cálculo de resultados fiscais e autorização de despesas em

1 Relatório e parecer prévio sobre as contas do governo da República - Exercício de 2014. Relator Ministro Augusto Nardes. Brasília: TCU, 2015.

2 Apresentadas no capítulo 6 do Relatório. 
desacordo com a legislação. Irregularidades graves que foram clara e minuciosamente analisadas no relatório de 800 páginas apresentado pelo relator, ministro Augusto Nardes, e não atingem apenas aspectos pontuais das finanças públicas. Caracterizam deslizes que "terminam por comprometer não apenas o equilíbrio das contas públicas como também refletem no bem-estar dos cidadãos”, levando a um descontrole fiscal que "compromete a execução de políticas públicas fundamentais para a sociedade (...) [e] o funcionamento dos serviços públicos" e amplia o endividamento público "que, por sua vez, representarão prejuízos à qualidade de vida da populaçãa". Ou seja, um conjunto de atos que afrontaram a Lei de Responsabilidade Fiscal e violaram os princípios do planejamento, da transparência, da prudência, do equilíbrio orçamentário e da legalidade, comprometendo as contas públicas.

Mais do que isso, o que se deve destacar é a função educativa da decisão, que permitirá fazer os ajustes necessários para que as irregularidades não voltem a se repetir e as medidas de aperfeiçoamento da gestão sejam tomadas, valorizando os recursos que estão cada vez mais escassos e não podem ser mal aplicados.

Como bem ressaltado recentemente, "o alcance histórico da decisão ocorrerá se ela significar, daqui por diante, uma mudança de comportamento dos governantes na forma como eles lidam com os orçamentos públicos - e com o dinheiro dos nossos impostos" e "a decisão do TCU, com as sanções que ela pode acarretar, dever servir como alerta definitivo de que não se pode mais continuar a tratar o dinheiro de nossos impostos com tamanha ligeireza. A Lei de Responsabilidade Fiscal deve ser efetivamente aplicada e até mesmo reforçada". ${ }^{3}$

3 Para acabar com o jogo do faz de conta. Revista Época, ed. 905, 12 de outubro de 2015, p. 90. 